\title{
FACTORS INFLUENCING THE QUALITY OF CREDIT IN COMMERCIAL BANKS OF VIETNAM
}

\author{
Ai Huu Tran \\ Mỹ Phan Thi Chieu \\ Van Hien University, Ho Chi Minh, Vietnam
}

The study aims to determine the factors affecting credit quality at commercial banks and analyze the degree of influence of those factors on credit quality. Usable data were collected from face-to-face interviews with 347 survey subjects - credit officers at the Head Office, credit directors of some bank branches, and credit officers of joint-stock commercial banks. The research results show that seven factors affecting credit quality can be arranged in the following descending order of impact, namely: Credit officer, Credit policy, Management capacity, Banking technology, Risk management, Organizational work, Mobilized capital. Basing on the obtained results, some solutions are proposed to improve the credit quality at commercial banks in Vietnam.

Keywords: credit quality, credit officers, commercial banks, Vietnam

\section{Introduction}

Currently, income from credit activities accounts for the largest proportion of banks' revenue. Although the COVID-19 epidemic's complications are now being prolonged, many banks are still confident in striving for profit growth thanks to effective revenue
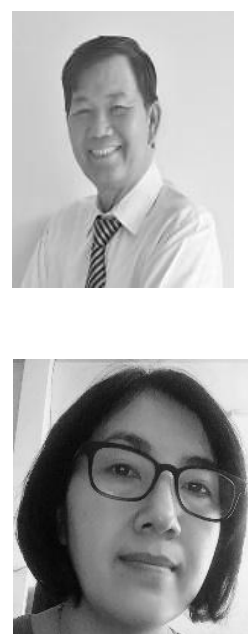

\section{Ai Tran Huu}

PhD, Lecturer of Faculty of Economics, Van Hien University, Ho Chi Minh City, Vietnam.

Research interests: markets of agricultural products; SMEs functioning under government support; organic food markets; corporate social responsibility.

E-mail: aith@vhu.edu.vn

\section{My Phan Thi Chieu}

MBA, Lecturer of Faculty of Economics,Van Hien University, Ho Chí Minh City, Vietnam.

Research interests: markets of agricultural products; organic food markets; ecological economics.

E-mail: MyPTC@vhu.edu.vn. 
diversification. The soaring profits of banks in the first quarter of 2021 can be explained by more optimistic credit growth and non-credit income as compared to the same period last year. In addition, banks also maintain good profit margins.

As the world is now entering the 4th Industrial Revolution, a revolution where advanced technologies such as virtual reality, the Internet of things, big data, artificial intelligence, etc. can be applicable to all the aspects of economic and social life. In this context, Vietnamese joint-stock commercial banks are gradually integrating, affirming the growth in all the aspects of their activities, especially credit activities, effectively serving the growth of the economy.

In 2021, Vietcombank plans to increase its total assets by $5 \%$; credit balance increased by $10.5 \%$ and adjusted according to the direction of the State Bank. Capital has been mobilized in accordance with the capital use demand, and it is expected to be $7 \%$. Consolidated bank's pre-tax profit increased by $11 \%$, of which, individual bank's profit was VND 25,000 billion. With the current foundation, Vietcombank's business results are expected to be very positive. Regarding the distribution of life insurance, last year VCB was ranked 13th at the market for life insurance distribution. In the first quarter of 2021, it went up to the 8th place with the total revenue recorded this year of more than VND 2,800 billion.

In 2021, Techcombank sets a profit before tax target to be around VND 19,800 bln, this is $25.3 \%$ up, as compared to the 2020 result. The credit balance is expected to reach nearly VND 356.2 trln, up by at least $125 \%$ as compared to the last year and within the level allowed by the State Bank (SBV). In the first quarter of 2021, Kienlongbank's consolidated pre-tax profit reached VND $702.62 \mathrm{bln}$. This rate of growth became possible thanks to the bank's cooperation with customers while handling all collateral assets and completing the recovery of principal and interest receivables of loans secured by the shares of Sacombank under the basic plan restructuring Kienlongbank in association with bad debt settlement as approved by the State Bank. In the context of the above practice, identification of the influencing factors as well as assessment of the influence of the credit quality factors under the current integration period needs to offer solutions in order to improve the credit quality of the joint-stock commercial banks in Vietnam as this is an urgent problem for many bank top managers in the country.

\section{Literature review}

Bank credit is a transaction of assets (money or goods) between a bank and a customer in which the lender transfers the property to the borrower for the use within a specified period of time, based on an agreement refund principle.

In the service sector, service quality can be defined in different ways, depending on the research object and research environment. For example, according to (Parasuraman et al., 1994), service quality is the gap between customers' expectations and their perceptions when using the service. And according to (Laidroo, 2017), service quality must be evaluated in two aspects: (1) service delivery process, and (2) service results. Nguyen Van Tien and Nguyen Thu Thuy (2014) introduced the concept of bank credit quality which, in their understanding, is the aggregate economic indicator, reflecting the level of meeting customers' reasonable loan requirements, in line with credit policy use, ensuring safety and bringing economic efficiency to the bank. At the same time, it also needs to be contributing to socioeconomic development promotion. 


\section{FACTORS INFLUENCING THE QUALITY}

This study approaches the research problem from the perspective that the credit quality of banks should be concerned with the two key objectives: (1) affirming the leading role in the credit system for the economy, (2) ensuring the achievement of growth, safety, and profitability of business capital in accordance with the planned objectives and legal regulations in each period.

Overview of the factors affecting credit quality carried out in the previous studies shows that there are quite many factors affecting the credit quality of banks, however, within the scope of this study, the authors would like to focus on the factors belonging to "the inside of a bank", that is, from the perspective of bank managers. In addition, the authors propose the element of "strictly controlling credit for potentially risky fields such as real estate, securities", that is supposed to be strengthening risk management of consumer credit within the group of customers with large outstanding loans, ensuring appropriate growth and striving to achieve a bad debt ratio of less than 2 .

In fact, after adverse shocks, in the case of the economies where the banking sector is well capitalized, bank lending tends to decline less. This indirectly proves that bank capital has the ability to absorb shocks of the economy. At the same time, the moral hazard problem is alleviated when banks are highly capitalized (Faiçal, 2014). Ahmed and Malik (2015), when studying the banking system crisis in developed and developing countries in the period 1980-1994, found that: banking crisis disrupted credit flows for households and businesses, reducing investment and consumption and driving businesses into bankruptcy. Because bank activities have a significant influence on the economy, their regulation must be strict and must include banking supervision (Al-Haj, 2004).

\section{Hypotheses and research models}

\section{Research hypothesis}

Credit policy: to implement a credit strategy management or the Board sets forth the policies that become the basis for the formation of the credit process with detailed professional instructions and specific steps in the credit granting process. Credit policy also stipulates loan limits for customers, debt classification, provisioning, etc. This policy must outline the operational direction for credit officers and provide a clear frame of reference to serve as a basis for considering loan needs.

Therefore, our hypothesis $\mathrm{H} 1$ can be formulated as follows:

The higher the credit policy, the better the lending activity and vice versa.

In other words, credit policy and credit quality have a positive relationship.

Management capacity: Credit management is always the most important tool for bank leaders through which they conduct governance, according to the planned credit strategy and policy. The general principle while building an effective organizational structure is to separate the strategic planning function of the Board of Directors, the function of organizing and operating the Board of Directors, and the function of monitoring and controlling the Board of Directors. Currently, in many banks, the organizational structure and credit administration are implemented according to two popular models, namely: centralized credit management model and distributed credit management model. There is also a combined model which has the elements of both centralization and distribution. That is, depending on the field, industry, type of product or service, or the customer, a centralized management 
model can be applied at the head office and become more decentralized, down to each branch.

Thus, we formulate our hypothesis $\mathrm{H} 2$ as follows:

Bank's management personnel with good knowledge and experience positively affects credit quality. Strict and scientific internal control and inspection activities are carried out regularly, thus positively impacting credit quality.

Banking technology: The financial/banking sector is an industry with a high level of information technology application. Today's advanced information technology systems are able to meet the requirements of accuracy, large transaction volume of customers, active and detailed search for customer information, help with decision-making while processing loans, etc. Equipment, machinery, other technical means, and information technologies available today are quite able to facilitate the simplification of procedures, shorten transaction time, faster and more accurate information collection, and cost-saving at the same time. Also, banks' information sources today are not only diversified but are also offering high rates of accuracy, thus positively affecting credit quality.

Therefore, we formulate our hypothesis $\mathrm{H} 3$ as follows:

Today's technological equipment, safe and reliable banking, credit assessment software have a positive impact on credit quality.

Credit risk management: Credit risk management is the process by which banks plan, organize, implement, and supervise all credit-granting activities in order to maximize profit in banks with an acceptable level of risk. Credit risk is the possibility that a customer will not meet his or her repayment obligations under agreed terms. Credit risk has many causes, but in general, the main reason is the implementation of the credit management process of commercial banks.

Thus, our hypothesis $\mathrm{H} 4$ is as follows:

Clear and detailed credit regulations and processes and compliance by credit officers have a positive impact on credit quality.

Organizational work: Credit organization and administration are always the most important tools for bank leaders while performing governance in accordance with the credit strategy and policy as planned and determined. The general principle of building an effective organizational structure is to separate the strategic planning function of the Board of Directors, the function of organizing and operating the Board of Directors, and the function of monitoring and controlling of the Board of Directors.

Therefore, our hypothesis H5 is formulated as follows:

Credit organization and administration are rated higher, the better the lending activity.

In other words, credit organization and administration and lending activities are positively correlated.

Credit officer: Human resources are central to all business activities of commercial banks, especially credit-related ones. Credit operations are getting increasingly complex today, requiring qualified personnel, capacity, thinking ability, sensitivity and professional 


\section{FACTORS INFLUENCING THE QUALITY}

ethics. These are the decisive factors for the success of the banking system's efficiency and improvement of credit quality.

Thus, our hypothesis H6 can be formulated as follows:

The higher the credit officer is rated, the better is the lending activity.

In other words, credit officers and the composition of lending activities are positively correlated.

Mobilized capital: This is the largest source of capital in almost any bank. This is the monetary value from economic organizations and individuals mobilized by a bank through the process of performing deposit and other operations to be used as capital for future business purposes. The nature of this mobilized capital is assets belonging to different owners, while the bank only has the right to use it without ownership and is responsible for timely repayment of both principal and interest when it is due (if it is a term deposit) or when the customer needs to withdraw capital (if it is a demand deposit). Mobilized capital plays a highly important role in business activities on any bank.

Thus, our hypothesis $\mathrm{H} 7$ can be formulated as follows:

Mobilized capital and credit planning are positively correlated.

\section{Research models}

Table 1 - Summary of the scales borrowed from other researchers (Source: Compiled by the authors from the sources directly mentioned in the table)

\begin{tabular}{|l|l|}
\hline Credit policy & $\begin{array}{l}\text { A. Burak Guner (2007), Faiçal Belaid (2014), Laivi Laidroo \& Kadri } \\
\text { Männasoo (2017) }\end{array}$ \\
\hline Management capacity & Faiçal Belaid (2014), \\
\hline Banking technology & Dương Thị Hoàn (2019); Laivi Laidroo \& Kadri Männasoo (2017) \\
\hline Risk management & Nguyễn Như Dương (2018; Laivi Laidroo \& Kadri Männasoo (2017) \\
\hline Organizational work & Nguyễn Như Dương (2018); Laivi Laidroo \& Kadri Männasoo (2017) \\
\hline Credit officer & Dương Thị Hoàn (2019); Laivi Laidroo \& Kadri Männasoo (2017) \\
\hline Mobilized capital & $\begin{array}{l}\text { Nguyễn Thị Thu Đông (2012); } \\
\text { Laivi Laidroo \& Kadri Männasoo (2017) }\end{array}$ \\
\hline
\end{tabular}

\section{Research Methodology}

This study has been conducted in two main phases: (1) Qualitative research to identify, adjust and supplement the scales affecting the credit quality of banks, (2) Formal research to collect and analyze the survey data, test scales, hypotheses, and research models.

In our previous study, the author already explored the factors affecting the credit quality of banks. Qualitative research was conducted with ten top managers at ten active banks in order to find the concordance between the observed variables and also to find new variables for potential observation.

The author has conducted a survey to test the concordance of the variables with the number of respondents being 50. Our survey participants have been managers and credit officers of joint stock commercial banks in Vietnam. The survey forms have been sent, 
directly or via email to staff members working in branches of various Vietnamese commercial banks.

Table 1 - Statistics on credit officers participating in the survey

(Source: Compiled by the authors)

\begin{tabular}{|c|c|c|}
\hline Demographics & Number & Valid, in $\%$ \\
\hline \multicolumn{3}{|l|}{ 1. Age } \\
\hline$<30$ y.o. & 42 & 12.10 \\
\hline 30-40 у.о. & 165 & 47.55 \\
\hline $41-50$ y.o. & 104 & 29.97 \\
\hline$>50$ y.o. & 36 & 10.37 \\
\hline Total & 347 & 100.00 \\
\hline \multicolumn{3}{|l|}{ 2. Gender } \\
\hline Male & 246 & 70.89 \\
\hline Female & 101 & 29.11 \\
\hline Total & 347 & 100.00 \\
\hline \multicolumn{3}{|l|}{ 3. Years of experience } \\
\hline$<5$ years & 40 & 10.23 \\
\hline 5 to 10 years & 176 & 45.01 \\
\hline 11 to 20 years & 129 & 32.99 \\
\hline $20+$ years & 46 & 11.76 \\
\hline Total & 391 & 100.00 \\
\hline \multicolumn{3}{|l|}{ 4. Working position } \\
\hline Director at headquarters & 58 & 16.71 \\
\hline On-site management & 104 & 29.97 \\
\hline $\begin{array}{l}\text { Directly working with } \\
\text { customers }\end{array}$ & 185 & 53.31 \\
\hline Total & 347 & 100.00 \\
\hline \multicolumn{3}{|l|}{ 5. Education level } \\
\hline University & 205 & 59.08 \\
\hline Postgraduate & 142 & 40.92 \\
\hline Total & 347 & 100 \\
\hline
\end{tabular}

\section{Data analysis methods}

The authors have distributed 400 questionnaire copies to the survey subjects. The number of valid returns has been 347 . Valid answers were then coded and entered into SPSS software to perform further analysis in steps. 


\section{FACTORS INFLUENCING THE QUALITY}

Scale: The scales used in this study are synthesized from the measurement scales that several foreign authors have been using in relation to banking sectors in other countries. However, these scales needed to be adjusted through qualitative research (with the help of group discussion). This discussion has been organized in Ho Chi Minh City with the aim to find the most suitable scales specifically for the banking industry of Vietnam.

Table 2 - Cronbach's Alpha test results before EFA analysis (Source: Compiled by the authors)

\begin{tabular}{|c|l|c|c|c|}
\hline No & \multicolumn{1}{|c|}{ Scales } & $\begin{array}{c}\text { Number of observed } \\
\text { variables }\end{array}$ & $\begin{array}{c}\text { Cronbach's } \\
\text { Alpha }\end{array}$ & $\begin{array}{c}\text { Cronbach's Alpha } \\
\text { if Item Deleted }\end{array}$ \\
\hline 1 & Credit policy & 5 & 0,882 & 0,553 \\
\hline 2 & Management capacity & 5 & 0,894 & 0,646 \\
\hline 3 & Banking technology & 5 & 0,845 & 0,556 \\
\hline 4 & Risk management & 4 & 0,817 & 0,533 \\
\hline 5 & Organizational work & 5 & 0,845 & 0,512 \\
\hline 6 & Credit officer & 5 & 0,832 & 0,542 \\
\hline 7 & Mobilized capital & 4 & 0,883 & 0,526 \\
\hline 8 & Bank credit quality & 4 & 0,683 & 0,406 \\
\hline
\end{tabular}

- Evaluation of the scale: First, the scales will be preliminarily evaluated through two methods: Cronbach's Alpha reliability coefficient and the exploratory factor analysis (EFA). Next, the scales were tested by means of confirmatory factor analysis (CFA).

- Theoretical model testing: Along with confirmatory factor analysis (CFA), model testing has been carried out through AMOS 23 linear structural analysis software.

In the multiple regression model, we have the additional hypothesis that the independent variables are not completely correlated with each other. Thus, when estimating the multiple regression model, this assumption must be tested through testing the phenomenon of multicollinearity.

We use the VIF index (the Variance Inflation Factor). Usually, if VIF of a certain variable is $>2$, then this variable has almost no explanatory value for the variable $Y$ in the model (Hair et al., 2006). And if VIF of a variable $<2$, it is assumed that multicollinearity does not occur. Actually, if VIF $>2$, we must be cautious in interpreting regression weights as such (Nguyen Dinh Tho, 2011, p. 497).

\section{Results}

The analysis results for Cronbach's Alpha reliability coefficient of the scale are $0.835>$ 0.7. At the same time, all the six observed variables have the total correlation of $>0.3$. Thus, the obtained results meet the reliability criteria. 
The synthesized EFA shows 33 observed variables in 7 factors affecting bank credit quality. The results of EFA for the seven factors affecting bank credit quality are as follows. With the KMO coefficient $=0.833$, EFA is in agreement with the data, and the Bartlett Chisquare test is $7,149,151$, the significance level $p=0.000$. Thus, the observed variables are correlated with each other on the overall scale. The extracted variance 73.380 shows that the factors derive from $73.380 \%$ of the explanatory variance in data, the eigenvalues in the system are equal to 1.181 .

\section{Confirmatory factor analysis (CFA)}

The linear structural analysis shows that the chi-squared statistics of the model is 328.505 with 184 degrees of freedom and the value of $\mathrm{P}=0000$. The relative degrees of freedom of chi-square in Cmin/def is $1.785(<3)$. Other indicators demonstrate the following results: TLI $=0.941(>0.9)$, GFI $=0.908(>0.9)$, CFI $=0.953(>0.9)$ and $\mathrm{RMSEA}=0.052$ $(<0.08)$. Therefore, this model is suitable for the collected data. This allows us to draw individual statements about the direction of the observed variables. For the convergence of values, the normalized weights of the scales are $>0.5$ with the statistical significance of $\mathrm{P}<$ 0.05 , so the scale achieves a convergent value.

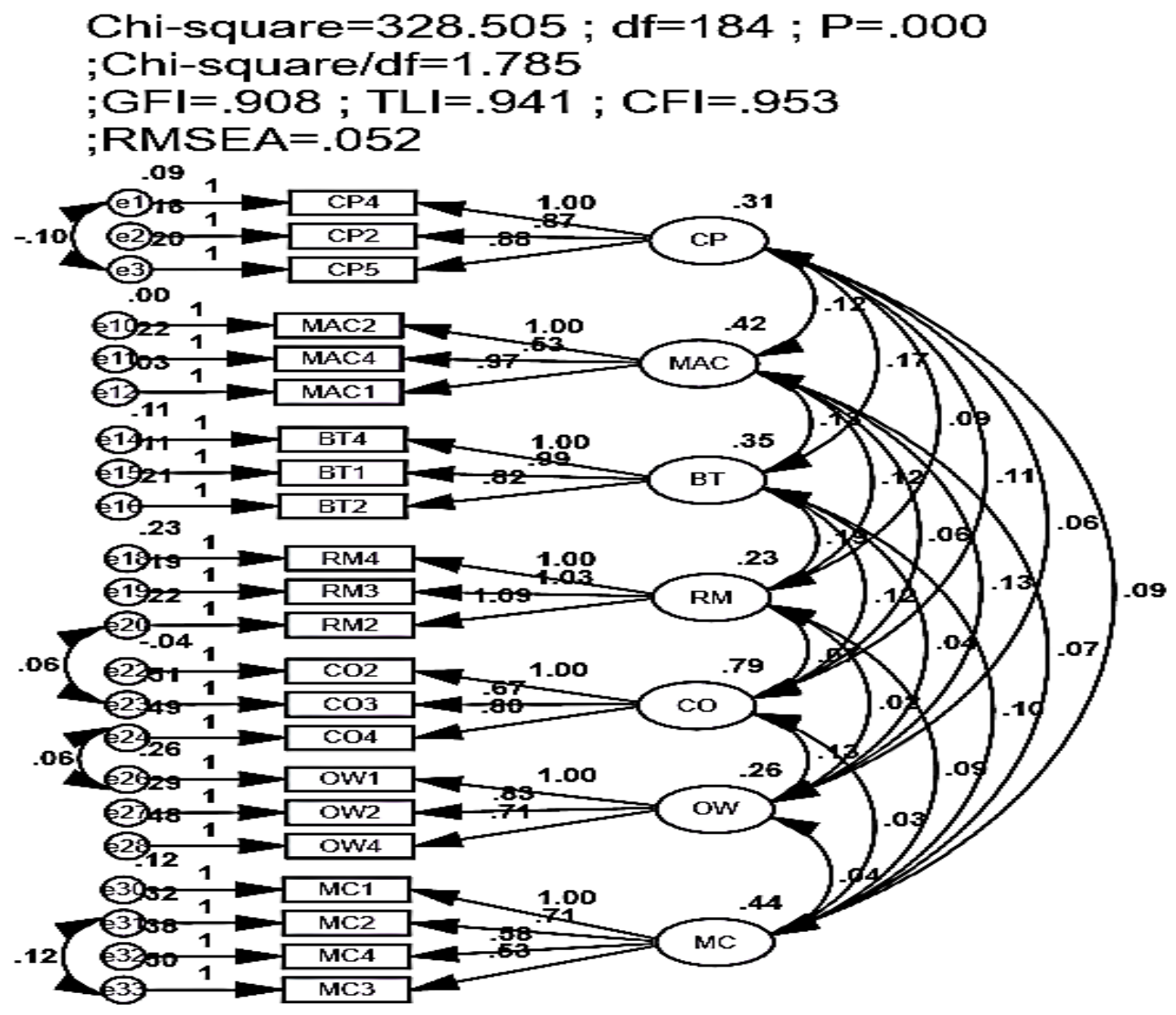

Figure 2 - Model structure after final calibration in CFA

(Source: Compiled by the authors) 


\section{FACTORS INFLUENCING THE QUALITY}

\section{Structural equation modeling results}

The table shows the results of the best fit for both the immediate structural behavior of the credit quality management factors and the borrower factors. The structural model here results in two data sets. The appropriate model index, Chi-square (X2), was used in this study to examine the relationship between the variables in the model (Hair et al., 2006). The AMOS results presented in Table 3 show that the models are fully equipped with data, therefore, the proposed model is appropriate in explaining the relationship between variables.

Table 3 - SEM analysis results of the model

(Source: Compiled by the authors)

\begin{tabular}{|c|c|c|c|c|c|c|c|c|c|c|}
\hline & & & Goo & ess of fit meas & $-\mathrm{X} 2 / \mathrm{df}$ & & & & & \\
\hline Model & $\mathrm{X} 2$ & Df & $\mathrm{p}$ & (CMIN/DF) & RMSEA & NFI & RFI & IFI & TLI & CFI \\
\hline Sample & 523.396 & 242 & 0.0 & 2.163 & .063 & .891 & .946 & .9 & .923 & .938 \\
\hline Criteria & $\mathrm{P}<.05$ & $\geq 0$ & - & 2 to 3 & $<.08$ & $>.80$ & $>.90$ & $>.90$ & $>.90$ & $>.90$ \\
\hline
\end{tabular}

Note: X2 = Chi-squared test, Df $=$ Degrees of freedom, RMSEA $=$ Root mean square error of approximation, NFI $=$ Normative index of conformity, RFI = Relative index of fit, IFI = Incremental Fit Index, TLI = Tucker-Lewis Index, CFI = Comparative Fit Index.

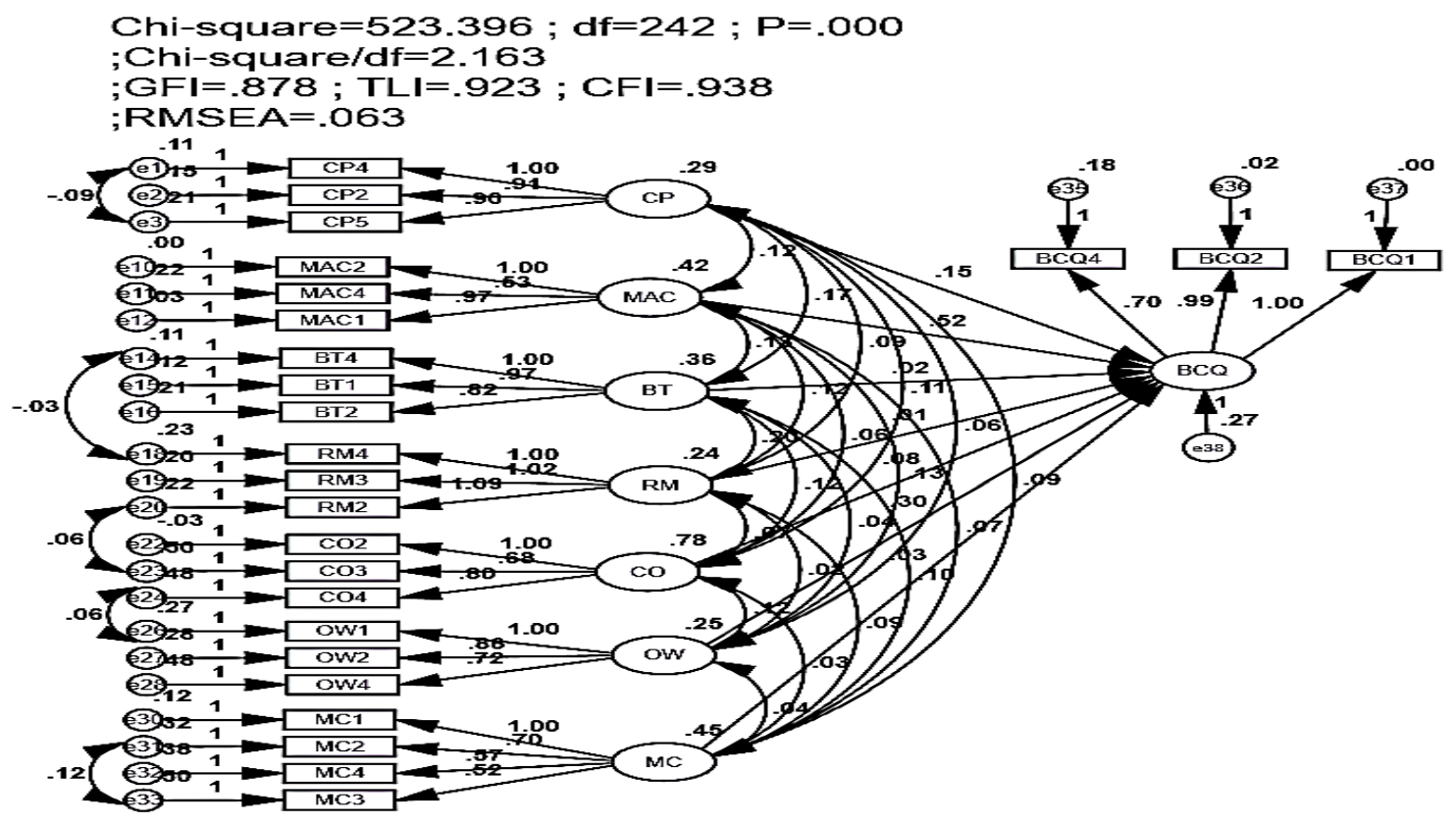

Figure 3. The model structure after final calibration in SEM

(Source: Authors' own calculations in SPSS Amos 23.0)

Thus, this model achieves compatibility with the already collected data. The factors under consideration include: (1) Credit policy ( $\mathrm{ES}=0.147 ; \mathrm{P}=0.045)$; (2) Management capacity ( $\mathrm{ES}=0.520 ; \mathrm{P}=0.000)$, (3) Banking technology $(\mathrm{ES}=0.017 ; \mathrm{P}=0.040)$, (4) Organizational factors $(E S=0.303 ; \mathrm{P}=0.012),(5)$ Credit officer $(\mathrm{ES}=0.077 ; \mathrm{P}=0.022)$, (6) Mobilized capital ( $\mathrm{ES}=0.027 ; \mathrm{P}=0.033)$, (7) Risk management $(\mathrm{ES}=0.025 ; \mathrm{P}=$ $0.019)$, all with $\mathrm{P}<0.05$ and the normalized estimate values. 
Table 4 - Results of estimating the causal relationship between the factors of bank credit quality

(Source: Compiled by the authors)

\begin{tabular}{|lcc|ccccc|}
\hline & Relationship & & Estimate & S.E. & C.R. & P & Label \\
\hline BCQ & $<---$ & CP & .147 & .078 & 1.843 & .045 & Yes \\
BCQ & $<---$ & MAC & .520 & .065 & 7.925 & $* * *$ & Yes \\
BCQ & $<---$ & BT & .017 & .093 & .305 & .040 & Yes \\
BCQ & $<---$ & RM & .025 & .069 & 1.888 & .019 & Yes \\
BCQ & $<---$ & CO & .077 & .077 & 2.290 & .022 & Yes \\
BCQ & $<---$ & OW & .303 & .057 & 1.742 & .012 & Yes \\
BCQ & $<---$ & MC & .027 & .047 & .717 & .033 & Yes \\
\hline
\end{tabular}

The bootstrap method is usually used to test the model estimates, with the pattern repeatedly being $\mathrm{N}=1000$. The estimation results for 1000 samples averaged together with the deviations are presented in Table 5. CR has a very small absolute value, thus, it can be stated that the deviation is very low, while also being not statistically significant at the $95 \%$ confidence level. Thus, we can conclude that the model estimates can be trusted.

Table 5 - Results estimated by means of bootstrap, $\mathrm{N}=1000$

(Source: Compiled by the authors)

\begin{tabular}{|lll|c|c|c|c|c|c|}
\hline \multicolumn{2}{|c|}{ Parameter } & SE & SE-SE & Mean & Bias & SE-Bias & CR \\
\hline BCQ & $<--$ & CP & 0.12 & 0.003 & 0.154 & 0.007 & 0.004 & 0.57 \\
\hline BCQ & $<--$ & MAC & 0.092 & 0.002 & 0.512 & -0.008 & 0.003 & -0.38 \\
\hline BCQ & $<--$ & BT & 0.107 & 0.002 & 0.036 & 0.018 & 0.003 & 0.17 \\
\hline BCQ & $<---$ & RM & 0.118 & 0.003 & -0.008 & -0.013 & 0.004 & -0.31 \\
\hline BCQ & $<---$ & CO & 0.045 & 0.001 & 0.074 & -0.003 & 0.001 & -0.33 \\
\hline BCQ & $<---$ & OW & 0.195 & 0.004 & 0.333 & 0.029 & 0.006 & 0.21 \\
\hline BCQ & $<---$ & MC & 0.059 & 0.001 & 0.026 & -0.001 & 0.002 & -2.00 \\
\hline
\end{tabular}

\section{Conclusion}

\section{Management capacity}

According to the survey results at commercial banks, the factor of management capacity has the most positive influence on the credit quality of banks with the standardized beta coefficient $(\beta=0.520)$ and the statistical significance of over 95\% $(\mathrm{Sig}=0.012)$.

The banks have issued a sufficient number of internal documents for guiding their credit activities. Accordingly, credit-granting activities are carried out according to a closely built credit process, with connection, inheritance, and content of mutual control between all the steps needed. The banks have separated the work between the staff performing business, loan, appraisal, special assets appraisal, and approval level, meeting the four-eyes principle in their internal control. The shift from a decentralized credit appraisal \& approval 


\section{FACTORS INFLUENCING THE QUALITY}

mechanism at branches to a centralized credit appraisal \& approval mechanism at the head office also plays an important role for minimizing errors in credit decision-making.

\section{Organizational work}

According to the survey results at Vietnamese commercial banks, the factor of organizational work with a standardized beta coefficient $(\beta=0.303)$ and the statistical significance of over $95 \%$ ( $\mathrm{Sig}=0.012)$ has the second strongest impact on the credit quality of banks.

Our survey of credit officers at commercial banks shows that all the banks have internal control processes. Depending on the needs, size, and characteristics of each bank, the choice of a credit risk management model is different, however, each bank combines its credit risk management with a credit risk management model. The three lines of control are as follows:

- The first line of control is sales managers and customer service specialists working at branches and also operating units at the head office.

- The second line of control is risk management as well as compliance, operational, and legal risk management.

- The third line of control is the internal audit department.

\section{Credit policy}

According to the survey results at commercial banks, the factor of credit strategy and policy with the standardized beta coefficient $(\beta=0.147)$ and the statistical significance of over $95 \%(\operatorname{Sig}=0.045)$ has the third strongest impact on the credit quality of banks.

A system of processes, regulations, and credit policies has been introduced to ensure that the credit granting process is carried out consistently from the Head Office to branches, creating an effective monitoring mechanism to limit and prevent risks and promote credit quality improvement. The system of documents and credit policies mainly includes credit strategy and policy, customer policy, credit granting process, decentralization of credit decision-making, regulations supporting the credit granting process. According to international practices and Basel 2 standards, banks must have a specific, long-term business strategy and develop their own credit risk policy.

\section{Credit officers}

According to our survey results, the factor of risk management with the standardized beta coefficient $(\beta=0.077)$ and the statistical significance of over 95\% ( $\mathrm{Sig}=0.022)$ has the fourth strongest impact on the credit quality of banks.

The survey of credit officers at Vietnamese commercial banks has shown that the banks' HR policies were developed in detail, with the standardized title system and personnel allocation, and a well-developed set of standards. This allows evaluating the work results of employees, implementing the performance management system and thus innovating the salary and bonus system.

Some banks have also implemented the assessment and capacity-building programs according to the international standards, aiming to strengthen the leadership team with extensive domestic and international experience. 


\section{Risk management}

According to the survey results, the factor of risk management with the standardized beta coefficient $(\beta=0.025)$ and the statistical significance of over 95\% ( $\mathrm{Sig}=0.019)$ has the fifth strongest impact on the credit quality of banks.

Most of the investigated banks carry out credit risk identification while assessing their customers. Besides, in order for credit officers to be able to comprehensively identify and limit credit risks that may arise, the credit risk identification system needs to have support in other internal documents of banks related to credit risk management. Changes that may have the greatest impact on credit activities need to be detected in a timely manner and according to the decentralization principles.

\section{Mobilized capital}

According to the survey results, the factor of mobilized capital with the standardized beta coefficient $(\beta=0.027)$ and the statistical significance of over $95 \%$ ( $\mathrm{Sig}=0.33$ ) has the sixth strongest impact on the credit quality of banks.

These days, in the context of the international financial and monetary markets development, many complications arise, especially due to the influence of the US-China trade war and other issues. Both state-owned and private corporations are facing financial difficulties, and Vietnamese commercial banking system is no exception since it is going now through the process of restructuring, dealing with bad debts and capital divestment. Both state-owned enterprises and banks in Vietnam depend greatly on the recovery of the economy overall, changing market conditions and development of business activities in the country.

\section{Banking technology}

According to the survey results, the factor of banking technology with the standardized Beta coefficient $(\beta=0.017)$ and the statistical significance of over $95 \%$ (Sig $=0.040)$ has the seventh strongest impact on the credit quality of banks.

All surveyed Vietnamese commercial banks have applied advanced technologies to build their own data warehouses to support their forecasting and analysis for better business decision-making which would be contributing to improving competitiveness and efficiency. As a result, internal information exchange within banks seems to be relatively convenient and well developed, since all necessary information on credit activities is promptly updated and proactively sent to credit officers according to the principles of decentralized access.

One of the communication methods in relation to credit activities is annual reporting of banks. Important indicators related to credit activities and present in such reporting include: outstanding loans, their structure, bad debts, interest income. Most of this data is clearly and fairly shown by most banks in their annual reports. Before being released to the public, banks' annual reports are audited by major auditing companies, such as PWC, KPMG, Ernst $\&$ Young, and Deloitte. This additionally contributes to reliability of the bank data.

\section{Limitations of this research study}

The study has certain limitations due to the fact that it is based on the survey data. The main one is that all our respondents were from the same city. Thus, it would be more convincing if the survey has been organized in several localities instead. Also, obviously, 


\section{FACTORS INFLUENCING THE QUALITY}

there are other factors that are also affecting the credit quality of banks but these factors were not covered by our study.

\section{References:}

Al-Hajj (2004). Criteria for direct credit facilities in the Palestinian Islamic banks. Najah University Journal for Research Humanities, 18 (2).

Ahmed, S. F. \& Malik, Q. A. (2015). International Journal of Economics and Financial Issues, 5(2), 574-579.

Duong Thi Hoan (2019). Factors affecting credit quality at Vietnamese joint-stock commercial banks. Science \& Technology Magazine, 50, 118-122.

Burak Guner, A. (2007). Global investors, bank lending opportunities and credit standards. Journal of Financial stability, 4, 62-87.

Faiçal, B. (2014). Loan Quality Determinants: Evaluating the Contribution of Bank-Specific Variables, Macroeconomic Factors and Firm Level Information. Graduate Institute of International and Development Studies Working Paper, 04.

Hair et al. (1998). Multivariate Data Analysis. Prentice-Hall International, Inc.

Laidroo, L. \& Männasoo, K. (2017). Do credit commitments compromise credit quality? Research in International Business and Finance, 41(c), 303-317.

Nguyen Nhu Duong (2018). Credit risk management solutions at Joint Stock Commercial Bank for Industry and Trade of Vietnam, Ph.D. thesis in Economics.

Nguyen Van Tien \& Nguyen Thu Thuy (2014). Principles and operations of commercial banking, Statistical Publishing House.

Paper submitted

Paper accepted for publishing

Paper published online
29 April 2021

16 June 2021

31 July 2021 